\title{
Hubungan Authoritarian Parenting dengan Impostor Syndrome padaMahasiswa Salah Jurusan
}

\author{
Lydia Indira* dan Martha Ayu \\ Fakultas Psikologi Universitas Jayabaya \\ * Corresponding author: lydia.indira2016@gmail.com
}

\begin{abstract}
In the family background, there are parenting styles that are associated as a factor in the emergence of Impostor Syndrome, namely authoritarian parenting, where parents have excessive protection for their children and apply rules and have special standards that must be met by children. In the case of students who took the wrong major, it is often found that the process for taking a major is determined by the parents. They can only follow because it is a form of obedience so that sometimes they feel that what they are living is just a compulsion. During their studies, they feel forced, but their academic scores are not disturbed and even tend to be good and high achievers. This study aims to see the relationship between authoritarian parenting and Impostor Syndrome in students who took the wrong major. The research subjects were 100 people using a purposive sampling technique. Methods of data analysis using statistical correlation test method, product-moment correlation based on data analysis, it was found that there was a positive relationship between authoritarian parenting and Impostor Syndrome in students who took the wrong major. This can be seen from the acquisition of a correlation coefficient of 0.230 with a significance level of 0.05 .
\end{abstract}

\begin{abstract}
Abstrak
Dalam latar belakang keluarga terdapat pola asuh yang dikaitkan sebagai faktor munculnya Impostor Syndrome yaitu authoritarian parenting dimana orang tua memiliki proteksi yang berlebihan kepada anak dan menerapkan aturan serta memiliki standar khusus yang harus dipenuhi oleh anak. Pada kasus mahasiswa salah jurusan sering ditemukan bahwa proses untuk pengambilan jurusan ditentukan oleh orang tua. Mereka hanya bisa mengikuti karena ini bentuk kepatuhan, sehingga terkadang mereka merasa jika apa yang mereka jalani ini hanyalah sebuah keterpaksaan. Selama menjalani perkuliahan mereka merasa terpaksa, akan tetapi nilai akademis mereka tidak terganggu bahkan cenderung memiliki nilai-nilai yang baik dan berprestasi. Penelitian ini bertujuan untuk melihat hubungan antara authoritarian parenting dengan Impostor Syndrome pada mahasiwa salah jurusan. Subjek penelitian berjumlah 100 orang dengan menggunakan teknik purposive sampling. Metode analisa data menggunakan metode uji korelasi statistik yaitu korelasi product moment. Berdasarkan analisis data ditemukan bahwa terdapat hubungan yang arahnya positif antara authoritarian parenting dengan Impostor Syndrome pada mahasiswa salah jurusan. Hal ini terlihat dari perolehan angka koefisien korelasinya yang sebesar 0,230 dengan tingkat signifikansi 0,05 .
\end{abstract}

Keywords): Authoritarian Parenting, Impostor Syndrome, Mahasiswa Salah Jurusan. 


\section{PENDAHULUAN}

Bagi sebagian anak, memilih jurusan kuliah bukan merupakan perkara yang mudah. Beberapa mungkin sudah mempersiapkan dari jauh-jauh hari, namun yang lainnya masih belum tahu tentang gambaran jurusan yang nantinya akan dipilih. Seringkali keputusan pemilihan jurusan dipengaruhi oleh berbagai pihak, seperti teman-teman, orang tua dan masyarakat. Mahasiswa yang salah jurusan tidak semuanya memiliki prestasi buruk, terkadang mereka memiliki Indeks Prestasi yang cukup baik yaitu tiga koma ke atas dan memiliki prestasi, namun mereka merasa bahwa prestasinya tidak layak didapatkan karena mereka merasa tidak memiliki kemampuan tersebut.

Impostor Syndrome adalah gangguan penyemu dimana kita menjalani hidup dengan adanya rasa meragukan diri sendiri. Menurut Sandi Mann (2019) penderita gangguan ini memiliki keyakinan bahwa pencapaian prestasinya merupakan hasil keberuntungan daripada ketrampilan yang dimiliki. Ini adalah fenomena psikologis yang dikenal sebagai "Impostor Syndrome". Dr. Maria Klawe, presiden Harvey Mudd College California yang merasa dia seorang penderita Imposter. Setiap ia dipromosikan pada jabatan tertentu, ia tidak nyaman karena merasa bukan yang ahli di posisi tersebut. Ia melakukan survey pada mahasiswa baru di collegenya. Setiap awal tahun ajaran baru, ia mengadakan pertemuan dengan seluruh siswa baru dan menanyakan apakah mereka merasa bahwa diterimanya mereka di Harvey Mudd College karena ada kesalahan dalam panitia penerimaan ? Setengah dari siswa itu mengangkat tangannya. Saat mahasiswa baru menghadapi tantangan di semester pertamanya, mereka merasa ragu apakah mereka sepandai siswa lainnya? Dan mereka khawatir suatu saat teman-temannya akan mengetahui kebodohannya. Perasaan seperti ini dikatakan sebagai Impostor Syndrome.

Impostor Syndrome sering dikaitkan atau disamakan dengan gejala low self esteem. Menurut Rosenberg and Owen (2001) low self esteem atau rendah diri adalah keyakinan pada seseorang dimana mereka merasa terganggu dengan kegagalan yang ia dapat dan cenderung membesar-besarkan peristiwa kegagalan secara negatif. Pengertian ini berbeda dengan Impostor Syndrome karena gangguan ini bukan hanya masalah harga diri atau rendah diri. Ini merupakan fenomena psikologis yang muncul dari penilaian yang salah terhadap kemampuan diri sendiri dibanding dengan orang lain. Menurut Pennarun (2014) gangguan penipu ini membuat orang pintar menjadi gelisah dan mempertanyakan tentang kapasitas diri mereka sendiri dan seringkali seseorang yang mengalami Impostor Syndrome tidak memahami kapasitas yang ada dalam dirinya. Mereka merasa tidak cukup layak menerima keberhasilan dan bahkan merasa tidak mampu menjalani sebuah tantangan dalam hidupnya. Hal ini muncul karena penilaian yang salah tentang kemampuan dirinya.

Clanse dan Imes (1978) mendefinisikan Impostor Syndrome sebagai pengalaman internal individu yang merasa dirinya tidak berharga, tidak memiliki potensi meskipun sebenarnya memiliki potensi dan berprestasi. Individu yang mengalami Impostor, merasa telah menipu orang lain, menganggap dirinya tidak seperti apa yang dilihat orang lain. Sedangkan menurut Sakulku dan Alexander (2011) Imposter muncul dari sosialisasi keluarga pada anak sejak usia dini dan diperkuat pada masa remaja hingga dewasa. Clance (dalam Sakulku dan Alexander) menyebutkan empat karakteristik umum dari keluarga yang berkontribusi terhadap Impostor Syndrome, yaitu orang tua membandingkan bakat masing-masing anggota keluarga, mereka menanamkan persepsi tentang pentingnya kemampuan intelektual dan keberhasilan, orang tua membandingkan prestasi anak yang satu dengan anak lainnya serta orang tua kurang memberikan feed back positif terhadap keberhasilan anak.. 
Selain itu hasil penelitian Clance menunjukkan bahwa perlindungan yang berlebihan dari orang tua berkorelasi positif dengan Impostor Syndrome. Perlindungan berlebihan orang tua mungkin akan menyebabkan hubungan yang mengecewakan antara orang tua dan anak-anak, hal ini juga dapat merusak kepercayaan diri anak dan harga diri anak. Anak-anak mungkin menafsirkan perlindungan berlebihan orang tua sebagai kurangnya kepercayaan pada kompetensi yang mereka miliki, menginternalisasi penilaian ini, yang selanjutnya meningkatkan kemungkinan mereka menderita Impostor Syndrome.

Menurut Santrock, pada dasarnya pola asuh merupakan gabungan dari respon, aturan, penerimaan serta tuntutan yang diberikan orang tua kepada anaknya (Santrock, 2011). Menurut Baumrind (dalam Santrock, 2011) ada empat macam jenis pola asuh yang biasanya diterapkan oleh orang tua yaitu :

- Pengasuhan otoritarian, yaitu gaya pengasuhan yang bersifat membatasi dan menghukum. Orang tua memberlakukan batas kendali yang tegas pada anak dan meminimalisir perdebatan verbal.

- Pengasuhan otoritatif, yaitu gaya yang mengarahkan anak untuk mandiri dengan tetap menerapkan batas dan kendali pada tindakan mereka.

- Pengasuhan yang mengabaikan yaitu, gaya pengasuhan di mana orang tua tidak memiliki keterlibatan dalam kehidupan anak.

- Pengasuhan yang memanjakan adalah gaya pengasuhan di mana orang tua sangat melibatkan dirinya dalam kehidupan anak, namun orang tua tidak terlalu banyak tuntutan dan tidak terlalu mengontrol anak mereka.

Berkaitan dengan pola asuh yang menjadi penyebab munculnya Impostor Syndrome, pola asuh yang merujuk kepada pengertian tersebut adalah authoritarian parenting. Orang tua otoriter memiliki harapan yang tinggi terhadap anak-anak mereka dan memiliki aturan yang sangat ketat yang mereka harapkan untuk diikuti tanpa syarat. Menurut Baumrind, orang tua ini berorientasi pada status, dan mengharapkan perintah mereka ditaati tanpa penjelasan.

Dalam konteks ini mahasiswa yang mengalami authoritarian parenting selalu merasa bahwa mereka harus mematuhi keinginan orang tua, terutama saat memilih jurusan kuliah. Konsultan perguruan tinggi Lynn O'Shaughnessy (NBC News, 2013) mengatakan dia sering mendengar bahwa keluarga tetap bersikeras mengatur jurusan kuliah yang tidak sesuai dengan minat atau kemampuan anaknya. Misalnya seorang anak berencana mengambil jurusan teknik, sementara orang tua memaksa anaknya untuk mengambil jurusan Akuntansi dan ia diberitahu oleh orang tuanya bahwa pendidikannya akan dibayar hanya jika dia mengambil jurusan akuntansi. Anak terpaksa mengambil jurusan sesuai keinginan orang tuanya, anak tetap menjalankan apa yang diperintahkan orang tua meskipun sangat menderita.

Hasil penelitian Sonnak dan Towell (2001) menunjukkan bahwa Imposter syndrom berhubungan dengan kurangnya perhatian orang tua, sedangkan dalam penelitian lain overprotection, yaitu perilaku melindungi yang berlebihan dari orang tua menjadi predictor kuat dari tingginya skor Imposter. Berdasarkan hal tersebut maka dalam penelitian ini ingin menguji apakah ada hubungan antara authoriatarian parenting, yaitu pola asuh yang menuntut anak untuk patuh tanpa memberikan penjelasan dengan Imposter sindrom. 


\section{METODE PENELITIAN}

\section{Rancangan Penelitian}

Desain penelitian yang digunakan dalam penelitian ini adalah penelitian kuantitatif korelasional. Sedangkan pengumpulan data menggunakan skala untuk menggali data mengenai authoritarian parenting dan Impostor Syndrome pada mahasiswa salah jurusan. Pengukuran disusun dan divalidasi melalui uji validitas dan reliabilitas. Uji validitas dan reliabilitas dilaksanakan dengan uji terpakai, artinya diuji secara parallel dengan pelaksanaan penelitian korelasional, item yang tidak valid tidak dihitung dalam penelitian.

\section{Identifikasi Variabel Penelitian}

a. Variabel Bebas (X) : Authoritarian Parenting

b. Variabel Terikat (Y) : Impostor Syndrome

\section{Definisi Operasional Variabel Penelitian}

\section{Authoritarian Parenting}

Authoritarian Parenting adalah gaya pengasuhan yang bersifat membatasi dan menghukum, di mana orang tua seringkali mendesak anak mereka untuk mengikuti arahan yang diperintahkan dan menghormati pekerjaan serta upaya mereka yang diukur melalui aspek kehangatan, aspek kontrol dan aspek komunikasi.

\section{Impostor Syndrome}

Impostor syndrome adalah perasaan dimana seseorang merasa kesuksesan mereka disebabkan oleh kebetulan atau keberuntungan atau usaha keras yang misterius dan bukan karena kemampuan dan kompetensi mereka sendiri, hal ini dapat diukur melalui fake, luck dan discount.

\section{Populasi dan Sampel Penelitian}

\section{Populasi}

Populasi yang akan digunakan dalam penelitian ini adalah mahasiswa di Jakarta yang tergabung dalam lima forum atau komunitas salah jurusan (Mahasiswa Baperan, Campus Pedia, Kini Bisa, Channel Hipwee dan Channel satu \%) .

\section{Karakteristik Sampel}

Sampel dalam penelitian ini memiliki karakteristik yaitu:

- Mahasiswa Jakarta laki-laki ataupun perempuan

- Usia 18-26 tahun

- Mahasiswa yang merasa salah jurusan pada rentang semester 2-8,

- Memiliki IPK diatas tiga.

\section{Subjek Penelitian}

Subyek dalam penelitian ini adalah 100 orang mahasiswa yang tergabung dalam komunitas salah jurusan. 


\section{Pengujian Alat Ukur}

\section{Skala Authoritarian Parenting}

\section{Uji Validitas}

Perhitungan uji validitas koefisien korelasi (r) item dilakukan dengan bantuan program SPSS 22.0, menggunakan koefisien korelasi Product-Moment Pearson. Skala beban kerja dalam bentuk kuesioner ini dikirimkan melalui aplikasi google form kepada sampel yang berjumlah 100 orang mahasiswa salah jurusan yang tergabung dalam lima komunitas. Hasil perhitungan $r$ sebesar 0,1966 sehingga apabila nilai $r$ hitung > $r$ tabel berarti suatu item dinyatakan valid dan apabila $r$ hitung < $r$ tabel berarti suatu item dinyatakan tidak valid. Dari tabel di atas, setelah uji validitas dengan menggunakan rumus Product Moment Pearson, maka diperoleh 40 item valid dengan batas nilai $\mathrm{r}$ hitung $>0,1966$ dengan $\mathrm{N}=100$. 5 item sisanya masuk dalam kategori tidak valid atau gugur dengan batas nilai $r$ hitung 0,1966 .

\section{Uji Reliabilitas}

Untuk menguji reliabilitas alat ukur dilakukan dengan menggunakan teknik pengukuran alpha crombach, dengan bantuan program SPSS 22.0. Dari hasil pengujian diperoleh reliabilitas $(\alpha)$ untuk skala Authoritarian Parenting adalah sebesar 0,936 dari 40 item. Hasil pengujian tersebut menunjukan koefisien yang reliabel karena koefisien reliabilitas $(\alpha)$ memiliki nilai $>\mathrm{r}$ tabel yaitu 0,1966. Artinya dari 40 item yang terdapat pada skala ini sudah konsisten untuk dilakukan ke tahap penelitian.

\section{Skala Impostor Syndrome}

\section{Teknik Pengujian Alat Ukur}

\section{Uji Validitas}

Kuesioner impostor syndrome yang digunakan dalam penelitian ini dari The Impostor Phenomenon berdasarkan teori dari Pauline Imes. Skala ini terdiri dari 30 item. Kuesioner diujikan melalui google form kepada sample yang berjumlah 100 orang mahasiswa salah jurusan yang tergabung dalam lima komunitas Setelah dilakukan uji validitas dengan rumus Product Moment Pearson, dari 30 item diperoleh 20 item yang valid dengan batas nilai $r$ hitung $>0,1966$ dengan $\mathrm{N}=100.20$ item sisanya masuk dalam kategori tidak valid atau gugur.

\section{Uji Reliabilitas}

Dari hasil pengujian diperoleh reliabilitas Alpha Cronbach $(\alpha)$ skala Impostor Syndrome sebesar 0,799 dari 20 item. Hasil uji tersebut menunjukan koefisien yang reliabel karena $(\alpha)$ memiliki nilai > $r$ tabel yaitu 0,1966 . Artinya 20 item yang terdapat pada skala ini sudah konsisten untuk dilakukan ke tahap penelitian.

\section{Analisis Data}

Metoda analisis data dalam penelitian ini didasarkan atas tujuan penelitian, yaitu untuk mengetahui hubungan antara Authoritarian Parenting dengan Impostor Syndrome pada mahasiswa salah jurusan yang tergabung dalam lima komunitas di Jakarta. Data penelitian ini 
dianalisis menggunakan uji korelasi product moment. Teknik ini digunakan karena kedua jenis data yang akan dikorelasikan berbentuk ordinal. Dalam pengerjaanya, uji korelasi akan dilakukan dengan bantuan program aplikasi komputer SPSS 22.

\section{HASIL DAN PEMBAHASAN \\ Hasil Analisis Korelasi}

Korelasi Authoritarian Parenting dengan Impostor Syndrome

\begin{tabular}{|ll|r|r|}
\hline & & $\begin{array}{r}\text { Authoritarian } \\
\text { Parenting }(X)\end{array}$ & $\begin{array}{c}\text { Impostor } \\
\text { Syndrome }(Y)\end{array}$ \\
\hline Authoritarian Parenting $(X)$ & Pearson Correlation & 1 & $.230^{\circ}$ \\
& Sig. (2-tailed) & & .021 \\
& $\mathrm{~N}$ & 100 & 100 \\
\hline Impostor Syndrome $(\mathrm{N})$ & Pearson Correlation & $.230^{\circ}$ & 1 \\
& Sig. (2-tailed) & .021 & \\
& $\mathrm{~N}$ & 100 & 100 \\
\hline
\end{tabular}

${ }^{*}$. Correlation is significant at the 0.05 level (2-tailed).

Dari tabel diatas dapat dilihat hasil penelitian antara Authoriatarian Parenting dengan Impostor Syndrome, dapat diperoleh nilai signifikansi sebesar 0,021. Dari hasil tersebut, dapat dilihat bahwa $p$ value (nilai signifikan) < alpha $(\alpha)$ yaitu $0,05(5 \%)$. Jadi $\mathrm{H}_{0}$ ditolak dan $\mathrm{H}_{1}$ diterima. Artinya ada hubungan yang signifikan antara Authoritarian Parenting dengan Impostor Syndrome yang arahnya positif dengan taraf signifikansi $95 \%$.

\section{Pembahasan}

Berdasarkan dari analisis korelasi antara Authoritarian Parenting dan Impostor Syndrome didapatkan bahwa ada hubungan signifikan antara Authoritarian Parenting dengan Impostor Syndrome. Hal itu menunjukkan bahwa Authoritarian Parenting berhubungan dengan Impostor Syndrome pada mahasiswa salah jurusan yang tergabung dalam lima komunitas di Jakarta yang arahnya positif. Artinya semakin tinggi Authoritarian Parenting semakin meningkat juga Impostor Syndrome.

Pada kasus ini orang tua memiliki pengaruh yang sangat besar terhadap terbentuknya fenomena Impostor Syndrome pada anak-anak mereka. Menurut Clance (1985) ketika bertemu dengan penderita Impostor Syndrome yang sudah dewasa, pesan atau perilaku yang diberikan oleh orang tua mereka di masa kanak-kanak adalah faktor pendorong munculnya Impostor Syndrome. Pesan yang biasanya diterima dari orang tua hanyalah kritik dan jarang mendapat pujian dari orang tua. Data penelitian menunjukkkan bahwa Orang tua mereka mengkritik banyak hal yang mereka lakukan dan tidak berkomentar ketika mereka berhasil meraih prestasi. Ketika seorang anak mendengar kritik yang konsisten untuk sesuatu yang tidak sempurna, mereka belajar bahwa tidak ada hal lain yang penting, orang tua hanya memperhatikan tentang kesalahan yang dilakukan oleh anak mereka. Di sisi lain, jika anak tidak pernah menerima pujian apa pun bahkan untuk sesuatu yang mengesankan, anak mungkin belajar untuk menganggap dirinya tidak memadai atau tidak memiliki kemampuan.

Bagi anak-anak, kebutuhan akan perhatian positif itu paling besar. Jika kebutuhan itu tidak terpenuhi, hal itu dapat terus merusak harga diri anak dan mengembangkan keraguan anak akan 
kemampuan dan inteligensinya. (Wilding, 2018). Hal ini tampak dari hasil penelitian yang menunjukkan bahwa Orang tua tidak peduli apa yang mereka lakukan, orang tua sibuk dengan pekerjaannya dan mereka tidak mendapat bimbingan ketika mengalami kesulitan. Saat menghadapi tugas atau ujian mereka merasa ragu dapat berhasil menyelesaikannya walaupun orang lain yakin bahwa dapat melakukannya dengan baik. Mereka merasa bahwa mereka tidak lebih pintar dari mahasiswa lainnya dan keberhasilannya selama ini merupakan factor keberuntungan,

Menurut Imes (dalam The American Psychological Association , 2018) menyatakan bahwa penekanan orang tua pada prestasi, dikombinasikan dengan tekanan masyarakat untuk sukses dapat meningkatkan efek impostor syndrome. Banyak orang yang berjuang dengan impostor syndrome melaporkan bahwa ia tumbuh dalam rumah di mana mereka dipuji karena kemampuan intelektual bawaan atau bakat alami saja, bukan karena kerja keras yang membawa kesuksesan. Fokus pada kemampuan alami sebagai penyebab pencapaian ini dapat menumbuhkan pandangan yang keliru tentang kesuksesan yang terus tumbuh saat seseorang memasuki masa dewasa, di mana mereka menghadapi tekanan masyarakat untuk berprestasi. Sehingga mereka merasa bahwa dirinya hanya beruntung ketika menggapai sebuah prestasi. Hal ini membuat anak merasa bahwa dirinya hanya beruntung ketika mendapatkan keberhasilan atau kesuksesan.

Clance (1985) juga mengemukakan pentingnya mendengarkan anak secara teratur dan meluangkan sedikit waktu untuk mendapatkan perhatian anak dan mendengarkan anak-anak berbicara. Mendengarkan berarti benar-benar mendengarkan, adalah cara kita membuat anak merasa dilihat dan didengar. Hal ini akan membuat perasaan orang-orang yang menderita impostor syndrome tidak bersembunyi di balik topeng (Escalante, 2019). Austin (2020) mengatakan terkadang orang tua yang lalai, kasar dan tidak pernah hadir mendorong anaknya agar berbakat secara intelektual dan sukses sejak usia dini. Dalam pengalaman ini, anak terdorong untuk berhasil karena keadaan keluarganya dan jarang menerima tanggapan positif dari sosok orang tua, sehingga ia merasa sulit untuk menerima pujian dan terlalu banyak bekerja terus-menerus karena jika dia berhenti, dia merasa semuanya berantakan, karena bagi orang tua prestasi dalam lingkungan akademis atau hal profesional lain sangat dihargai dan merupakan sumber validasi yang utama.

Beberapa hal yang memunculkan Impostor Syndrome pada anak terkait dengan authoritarian parenting, yaitu kemarahan dan konflik yang muncul dan tidak dikelola dengan baik dalam keluarga, komunikasi dan perilaku di rumah yang diatur oleh prosedur ketat tentang bagaimana melakukan sesuatu, orang tua tidak memberikan ruang untuk berdiskusi meskipun itu untuk masa depan anak, kurangnya memberi dukungan untuk kegiatan, pengalaman atau ketrampilan yang unik dan kompleks pada anak. Anak-anak juga dituntut untuk memenuhi kebutuhan dan keinginan orang tua mereka dan ini sering dikendalikan oleh validasi yang dianggap layak oleh orang tua. Mereka dibentuk untuk memenuhi harapan orang tua. Ketika sang anak gagal memenuhi ekspektasi ini, ada konsekuensi yang signifikan, seperti hilangnya cinta atau perhatian orang tua. Pengalaman ini sangat mirip dengan dinamika Impostor Syndrome yang merasa dirinya seperti penipu (fraud) jika dia terjebak dalam kesalahan atau kekurangannya diekspos ketika melakukan sesuatu (Austin, 2020).

Pada uraian di atas sudah dijelaskan beberapa hal yang merujuk pada tindakan authoritarian parenting yang berhubungan dengan munculnya Impostor Syndrome pada anak, kaitannya dengan kasus mahasiswa salah jurusan adalah seringkali mahasiswa memilih jurusan berdasarkan keingininan atau paksaan orang tua dan jurusan yang orang tua pilih biasanya cenderung sulit bagi mereka karena tidak sesuai dengan minatnya. Hal ini disebabkan karena 
mereka jarang berdiskusi dengan orang tua karena orang tua menerapkan komunikasi satu arah,sehingga mereka terpaksa mengikuti apa yang orang tua sarankan.

\section{KESIMPULAN}

Berdasarkan hasil penelitian dapat disimpulkan bahwa terdapat hubungan yang signifikan yang arahnya positif antara Authoritarian Parenting dengan Impostor Syndrome pada pada mahasiswa salah jurusan di beberapa komunitas di Jakarta.

Berdasarkan temuan yang diperoleh dalam penelitian ini, terdapat beberapa saran, antara lain:

a. Perlu mencari referensi yang lebih banyak tentang impostor syndrome karena dalampenelitian ini masih memiliki keterbatasan teori maupun sumber bacaan.

b. Membandingkan dampak dari pola asuh yang berbeda pada Impostor Syndrome.

\section{UCAPAN TERIMAKASIH}

Penelitian ini dapat dilaksanakan berkat dukungan dari mahasiswa di Jakarta yang tergabung dalam lima forum atau komunitas salah jurusan (Mahasiswa Baperan, Campus Pedia, Kini Bisa, Channel Hipwee dan Channel satu \%), yang telah memberikan respon yang baik dan bersedia mengisi kuesioner di sela-sela kesibukannya. Semoga semua dukungan dan bantuan tersebut mendapatkan Rahmat Allah SWT. Aamiin.

\section{DAFTAR PUSTAKA}

Austin, L. O., \& Austin, R. O. (2020). Own Your Greatness: Overcome Impostor Syndrome, BeatSelf-Doubt, and Succeed in Life. New York City: Ulysses Press.

Clance, P. R. (2013). Impostor Phenomenon. Retrieved from Pauline Rose Clance: https://paulineroseclance.com/impostor_phenomenon.html

Clance, P. R., \& Imes, S. A. (1978). The imposter phenomenon in high achieving women: Dynamics and therapeutic intervention. Psychotherapy: Theory, Research \& Practice, 15,241-247. doi:10.1037/h0086006

Dewar, G. (2017, Juni 6). Authoritarian parenting: What happens to the kids? Retrieved November 24, 2019, from Parenting Science: https://www.parentingscience.com/ authoritarian- parenting.html

Escalante, A. (2019, Oktober 23). How to Prevent Impostor Syndrome in Your Child. Retrieved from Psychology Today Web site: https://www.psychologytoday. com/us/blog/shouldstorm/201910/how-prevent-impostor-syndrome-in-your-child 
Hurlock, E. B. (1991). Psikologi perkembangan : suatu pendekatan sepanjang rentang kehidupan.

Jakarta: Erlangga.

Klawe, M. (2018, October 8). Let's Talk About Impostor Syndrome With Incoming Students. Retrieved from Forbes: https://www.forbes.com/sites/mariaklawe/ 2018/10/08/lets-talk- about-impostor-syndrome/\#4a87419361 fa

Mann, S. (2019). Why Do I Feel Like An Imposter? How To Understand With Impostor Syndrome.

Lancashire: Watkins.

Miller, M. J. (2010). Authoritarian Parenting:The Impact on Children. New Jersey: The Center for Christian Counseling \& Relationship Development.

O'Shaughnessy, L. (2013, November 26). Choosing The Wrong Academic Major. Retrieved fromCBS Interactive Inc: https://www.cbsnews.com/news/choosing-thewrong-academic- major/

Papalia, D. E., Olds, S. W., \& Feldman, R. D. (2008). Human development (psikologi perkembangan) bagian $V$ s/d bagian IX: masa remaja, masa dewasa awal, masa dewasa pertengahan, masa dewasa akhir, akhir sebuah kehidupan . Jakarta: Kencana.

Pennarun, A. (2014, Juli). National Post, Canadian Newspaper. The Curse of Smart People.

Retrieved from Apenwar: https://apenwarr.ca/log/20140701

Rosenberg, M., \& Owens, T. J. (2001). Low self-esteem people: A collective portrait. Sociological and Psychological Currents, 400-436. doi:10.1017/ CBO9780511527739.018

Sakulku, J., \& Alexander, J. (2011). The Impostor Phenomenon. International Journal of Behavioral Science, 6, 75-97.

Santrock, J. W. (2007). Remaja (11 ed.). (N. I. Sallama, Ed., \& B. Widyasinta, Trans.) Jakarta: Erlangga.

Santrock, J. W. (2011). Masa perkembangan anak buku 1. Jakarta: Salemba Humanika.

Sonnak, C., \& Towell, S. (2001, Oktober). Relationships between self-esteem, mental health, parental rearing style and socioeconomic status. Personality and Individual Differences, 863-874. doi:10.1016/S0191-8869(00)00184-7

Wilding, M. J. (2018, Juli 8). Crippled by Self-Doubt? Your Impostor Syndrome Could Have Roots in Childhood. Retrieved from Psych Central: https://psychcentral.com/blog/crippled-by- self-doubt-your-impostor-syndromecould-have-roots-in-childhood/ 